\title{
Spontaneous pneumomediastinum: two contrasting cases that highlight key aspects of management
}

\author{
Matthew David Kelham, ${ }^{1}$ Allan Zhifa Nghiem, ${ }^{2}$ April Lauren Goundry ${ }^{3}$
}

\begin{abstract}
${ }^{1}$ Brighton and Sussex University Hospitals NHS Trust, Brighton, UK

${ }^{2}$ Department of General Surgery, Newham University Hospital, London, UK ${ }^{3}$ Worthing Hospital, Worthing, UK
\end{abstract}

\section{Correspondence to} Dr Matthew David Kelham, m.kelham@nhs.net

Accepted 15 October 2014

\section{Q crosshark}

To cite: Kelham MD, Nghiem AZ, Goundry AL. BMJ Case Rep Published online: [please include Day Month Year] doi:10.1136/ bcr-2014-208005

\section{DESCRIPTION}

A 24-year-old woman presented with a 1-day history of neck tightness following a 10-day history of cough and left-sided chest pain. Her CT is shown in figure 1 , which reveals a pneumomediastinum, pneumothorax of the left lung and extensive subcutaneous emphysema that was clinically palpable. After discussion with the regional cardiothoracic unit, given the extent of the pneumothorax, she was managed with a chest drain and high flow oxygen. She was discharged on day 6 with chest radiography confirming resolution of the pneumomediastinum, pneumothorax and emphysema.

Figure 2 was taken from a 23-year-old man who presented with lower central chest and epigastric pain after a prolonged course of vomiting. On examination he was tender in the epigastrium. Chest CT revealed a pneumomediastinum but no other abnormalities. The history and the CT findings prompted an urgent contrast swallow in order to exclude Boerhaave's syndrome. After the contrast swallow was reported as normal and as the patient remained stable he was discharged home on day 6 with outpatient follow-up.

Spontaneous pneumomediastinum (SPM) is an uncommon condition defined by air in the

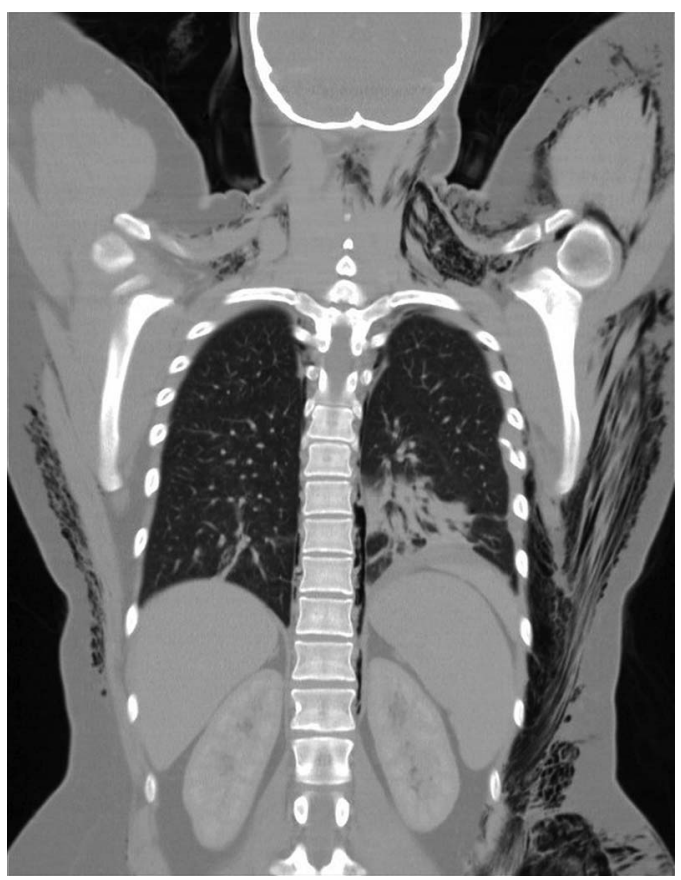

Figure 1 Coronal CT demonstrating pneumomediastinum, pneumothorax of the left lung and extensive surgical emphysema extending from the left chest wall to the neck but also evident on the right chest wall.

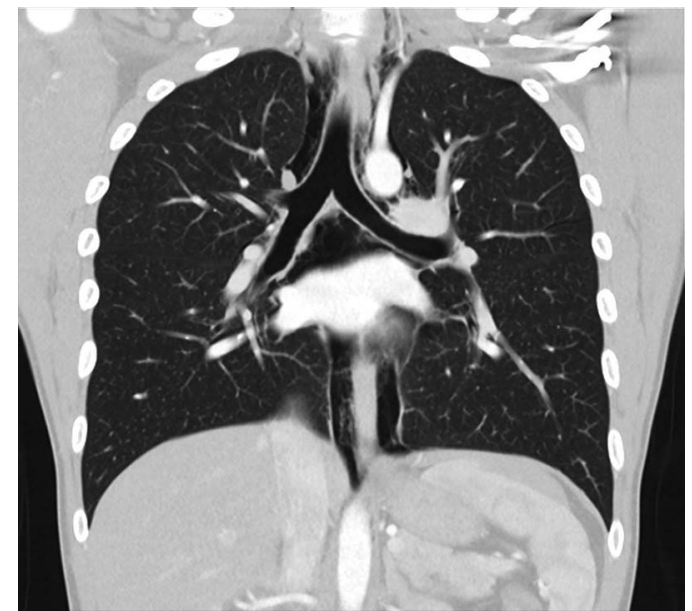

Figure 2 Coronal CT demonstrating pneumomediastinum extending all the way from the gastro-oesophageal junction up to the root of the neck. No abnormality in the lungs.

mediastinum without any obvious precipitating cause such as trauma or instrumentation. Pathophysiology is based on the Macklin effect whereby increased intrathoracic pressure leads to alveolar rupture and subsequent air dissection into the mediastinum and subcutaneous tissue. ${ }^{1}$ This may be due to coughing, vomiting or inhalational drug use. ${ }^{2}$ Case series suggest SPM is generally associated with a benign clinical course. ${ }^{3}$

\section{Learning points}

- Cases of spontaneous pneumomediastinum are usually associated with a benign clinical course.

- Chest drain insertion may be required in cases with concomitant pneumothorax.

- A swallow study should be considered in all patients presenting with vomiting and pneumomediastinum to rule out oesophageal rupture.

Contributors AZN was involved in the management of and decided on the most appropriate images to demonstrate for the patient shown in figure 1. ALG was involved in the management of and decided on the most appropriate images to demonstrate for the patient shown in figure 2. MDK performed the literature review and prepared the initial draft of the article.

Competing interests None.

Patient consent Obtained. 
Provenance and peer review Not commissioned; externally peer reviewed.

\section{REFERENCES}

1 Macklin CC. Transport of air along sheaths of pulmonic blood vessels from alveoli to mediastinum: clinical implications. Arch Intern Med 1939;64:913-26.
2 McCullough C, Keane MG, Hillman T, et al. Pneumomediastinum secondary to mephedrone inhalation. BMJ Case Rep 2013;2013: pii:bcr2013009961.

3 lyer VN, Joshi AY, Ryu JH. Spontaneous pneumomediastinum: analysis of 62 consecutive adult patient. Mayo Clin Proc 2009;84:417-21.

Copyright 2014 BMJ Publishing Group. All rights reserved. For permission to reuse any of this content visit

http://group.bmj.com/group/rights-licensing/permissions.

BMJ Case Report Fellows may re-use this article for personal use and teaching without any further permission.

Become a Fellow of BMJ Case Reports today and you can:

- Submit as many cases as you like

- Enjoy fast sympathetic peer review and rapid publication of accepted articles

- Access all the published articles

- Re-use any of the published material for personal use and teaching without further permission

For information on Institutional Fellowships contact consortiasales@bmjgroup.com

Visit casereports.bmj.com for more articles like this and to become a Fellow 